\title{
REVIEWS
}

Reviews of books, reports, papers and other publications should be sent to $J$. Walter Giles, Book Review Co-ordinator, Lands Branch, Department of Lands and Forests, Parliament Buildings, Toronto 5, Ont. Please mention that you saw the review in The Forestry Chronicle when purchasing books from publishers.

\section{Economics of the Pulp and Paper Industry}

(Ekonomika tselluloznobumazhnoi promyshlennosti). By U.V. Uchastkina. Goslezbumizdat. Moscow, 1963.

Written as a text-book for university students specializing in the pulp and paper industry the volume is a short, but comprehensive survey of the industry's organization and development. Published before Khrushchev was removed from power it is, to a certain extent, already out of date since its description of the industry's organization is based on regional Sovnarkhozy, i.e. before the return to the present structure based on ministries responsible for particular industries. This, however, is of minor significance and the book is a valuable source of information. It consists of twelve chapters dealing with past development, technical progress, organization and management, raw materials and power supply, location of enterprises, effects of concentration and specialization in the industry, construction and stocks of capital equipment, working capital productivity of labour, training and wages, and factors entering into and affecting costs of production. The last chapter is a brief survey of the pulp and paper industries of the countries of the Soviet block in Europe and also of China, North Korea, North Vietnam and Cuba. The book contains a number of graphs and statistical tables. Although there is not much that is new for serious students of the Soviet pulp and paper industry, the information is carefully selected and conveniently presented. In a rather subtle way the book is also a veiled plea to the authorities to make up for past neglect of the industry's interests. Deserving of special mention are the descriptions of planning procedure within the industry, the planned structure of inputs of raw materials and chemicals, and the norms accepted for the industry, the costs of transportation, amortization, procedure and rates. All in all, the book will be of great interest to anyone interested in the pulp and paper industry of the USSR from the academic point of view and also for comparing its operations and performance with those in other countries. It should really be translated to make it accessible to English speaking readers.

JAN SOLECKI

\section{REFORESTATION IN SPAIN}

By H. S. Kernan, State Univ. Col of For. at Syracuse Univ., Syracuse, N.Y., U.S.A. 52 p, $\$ 1.00$.

Without this publication, which is dedicated to the Foresters of Spain, the sessions of the Sixth World Forestry Congress would have given me few terms of reference for Spanish accomplishments in forestry. Having read it before going to Madrid I was able to understand something of what our hosts 
had achieved over the past 25 years. The drawings, photographs, and tables of costs per hectare ( 1 ha $=2.5$ acres $)$ provide impressive proof of the transformation of much severely abused mountain forest and brushlands to valuable stands contributing to economic development through multiple purpose forestry.

Over half of Spain (26.8 million ha) is "montes", land covered by trees or "wasteland whose sprouts, brush, and eroding hillsides are more accountable than any other single factor for the traditional poverty and backwardness of rural Spain". Of 116,000 ha reforested in 1964 less than 10 per cent was due to private efforts. The state reforestation program appears to be well and efficiently run with increasing attention being devoted to economics. Since 1958 it must make at least 4 per cent on its investments and may because it enjoys "clear-cut objectives, flexibility in adapting means to ends, and financial support consistent with the goals proposed". Although eucalypts and poplars are locally very important, various pine species represent more than 90 per cent of the reforestation effort. Radiata pine which grows particularly well in North West Spain has been planted by the State on about 60 thousand ha.

Total cut in 1964 was 5.5 million cubic meters $\left(1 \mathrm{~m}^{3}=35 \mathrm{cu}\right.$. ft. $)$. It is predicted that by 1970 yield will be 8 million $\mathrm{m}^{3}$, with more than half coming from plantations. Most of the increase in consumption is expected to come in the pulp and board industries with radiata pine and eucalypts increasing greatly in importance.

J. H. G. SMITH 